\title{
In search of relationship quality, customer retention and shareholder value: Findings from an exploratory, qualitative multiple case study
}

\author{
Adam Lindgreen ${ }^{1}$ \\ Unité Marketing, Institut d'Administration et Gestion, Université catholique de Louvain, 1, Place des Doyens, 1348 Louvain-la- \\ Neuve, Belgium; Tel: + 32 - 1047 8481; Fax+32 - 1047 8324; Email Lindgreen@mark.ucl.ac.be
}

\begin{abstract}
This article reports on the findings from an exploratory, qualitative first part of a research that (1) theorises that successful creation of shareholder value in relationship marketing and management requires relationship quality, which translates into customer retention, and that (2) models relationship quality and customer retention as key mediating variables in the creation of shareholder value. A multiple case study involving companies (in exporter-importer dyads) in the DanishBritish dairy sector, the Danish-British bacon sector and the New Zealand-British wine sector explored the key constructs of relationship quality; specifically, the cases examined whether or not the dimensions of relationship quality that Roberts (1998) and Roberts et al. (2000) have suggested are an appropriate framework. These dimensions are as follows: trust in credibility, trust in benevolence, commitment, conflict, satisfaction and social bonding. The evidence of the findings suggests that it does make sense to employ relationship quality as a concept in relationship marketing and management, and that the six dimensions are an appropriate framework for doing so. The managerial implications of the research findings are examined. The article concludes that there is a positive relationship between all of the antecedents of relationship quality (except for conflict), and that there is a positive relationship between customer retention and all of the consequences of customer retention (except for customer costs), and it proposes to test this idea in a confirmative, quantitative second part (using LISREL) in the context of the New Zealand-British wine sector.
\end{abstract}

Key words: customer retention, relationship management, relationship marketing, relationship quality, shareholder value

\section{Introduction}

It has been argued that agribusiness and the food industry traditionally have embraced transaction marketing (the 4Ps: product, price, promotion and place) and supply chain management (Barkema 1992; Barry et al. 1992; Kalfass 1993; Sporleder 1992). Over the past two decades, however, the terms relationship marketing and relationship management have emerged as alternative frameworks for thinking about marketing and management behaviour, postulating that a key task is to secure sustainable competitive advantage through relationships, networks and interactions because competing firms cannot easily duplicate these (Brodie et al., 1997; Buttle 1996; Christopher et al., 1991; Grönroos 2000; Gummesson 1999).

There are several sectors where relationship marketing and management are advanced, including the bank, hotel and hospital sectors. But agribusiness and the food industry represent an interesting opportunity for gaining possible insights into how firms are beginning to seek to employ constructs from relationship marketing and management: At the end of the 1990s, agribusiness and the food industry thus started to turn to relationship marketing and management (Behner et al., 1995; Hughes 1994; Srivastava et al., 1998; Tansey et al., 1995). For example, eight major consumer trends are driving the European food industry to become part of horizontal and vertical relationships. Agribusiness and the food industry also constitute a possible opportunity for achieving knowledge of how firms in one sector have learned from the experiences of firms in other sectors.

Despite the fact that relationship marketing and management were first introduced in the early 1980s (Berry 1983), there is still a lot of debate about what is meant by

\footnotetext{
${ }^{1}$ Warm thanks to the organisations that participated in this research. Equal thanks to professor Rod Brodie (the University of Auckland, New Zealand), senior lecturer Ian Crawford (Cranfield University, England) and professor emeritus Kjeld Porsdal Poulsen (Technical University of Denmark) for facilitating the fieldwork associated with this research and for suggestions during later stages of the research. Thanks also to researcher Arnold Boon (Danish Institute of Agricultural and Fisheries Economics, Denmark) and senior researchers Lasse Hinke and Per Eidnes Sørensen (both from Danish Bacon and Meat Council, Denmark) for advice during the initial stages of the research. I would also like to thank the two anonymous reviewers for their very useful comments.
} 
these terms.. It has been noted that they mean different things to different authors (Brodie et al., 1997; Cooper et al., 1997; Eiriz et al., 1999; Harker, 1999; Lindgreen et al., 1999). Indeed, Collins (1999) suggests that the language in the literature has imposed tunnel vision and that marketing should be banished from our relationship vocabulary and replaced with management, and Carlell and Mägi (1999) even contend that there is a lack of clarity of what is understood by the key term relationship. As a result, there is still little consistent story of how relationship marketing and management fit into the greater marketing landscape. The biggest challenge to the theoretical development of relationship marketing and management has perhaps been the lack of empirical investigations that aim at describing and exploring particular aspects of relationship marketing and management programmes implemented in real-life settings (Buttle et al., 2000; Collins, 1999; Lindgreen, 2001; Snehota et al., 1998).

\section{Relationships}

Fundamental to relationship marketing and management is relationships (Gummesson, 1999; Holmlund, 1997; Page et al., 1998; Roberts et al., 2000). The emphasis in most business models used to be on sick relationships instead of healthy relationships (Young et al., 1989): Two cases in point are the industrial marketing and marketing channels literature that have focused on power, conflict and control (O'Neal, 1989; Rosenbloom, 1991; Stern et al., 1992). With the concept of supply chain management, a more harmonious view of relationships was introduced; and, at the present time, authors argue that the confrontational model of buyer-seller relationships needs to be replaced with a more co-operative one (Davies, 1996; Lehmann, 1997; Lewin et al., 1997).

\section{Relationship quality}

Buttle et al. (2000) write that relationship quality should be of considerable corporate interest because of its possible commercial payoffs. They refer to Eriksson and Vaghult (1999) who suggest that there is a positive effect of relationship satisfaction on customer retention and purchase levels (see also Frisou, 1995); and to Hopkinson (2000) who observes that relationship quality results in a number of benefits for both the buyer and seller, including protection of the customer base and reduced propensity to switch. In a conceptual model of the dynamics of relationship quality that Storbacka et al. (1994) developed, service quality translates into customer satisfaction that again translates into first relationship strength, then relationship longevity and finally customer relationship profitability, as referred to by Buttle et al. (2000). See also Fornell (1992), Goderis (1998) and Reichheld (1996) who argue that customer satisfaction translates into higher customer retention; and Bolton et al. (1991) and Scheuing (1995) who find that customer satisfaction results in increased shareholder value. As a final example, Zeithaml et al., (1996) propose a nomological network in which relationship quality and service quality positively affect behavioural intentions that are said to lead to behavioural outcomes and increased customer lifetime value.

\section{Research issue}

Gummesson $(1997,1998)$ nevertheless notes that the measuring of returns on relationships is still in its infancy. In order to proceed, then, what is relationship quality? Buttle et al. (2000, p. 2) acknowledge:

"Despite this potential ... there is relatively little attention paid to the issue of relationship quality".

Roberts et al. (2000, p. 3) argue:

"Though several papers ... have measured the relationship quality between manufacturers and resellers and between salespersons and customers ... there is no tested scale by which service firms can begin to measure the quality of their relationship with customers and thus evaluate the success of their relational programs. Furthermore, it has not been empirically demonstrated whether the quality of the intangible aspects of a relationship adds any additional explanatory power over the commonly used service quality scale (SERVQUAL) in explaining behavioural intentions".

A number of models attempt to provide insight into the characteristics of strong buyer-seller relationships (Anderson et al. 1990; Mohr et al. 1994; Morgan et al. 1994). In a review of these models, Fontenot et al. (1997) identify ten constructs that are included to characterise a buyer-seller relationship: co-operation, interdependence, commitment, trust, opportunistic behaviour, communication, conflict, power, shared values and relationship outcome. Seeking to conceptualise relationship quality, Holmlund $(1996,1997)$ argues that relationship quality is influenced by the quality of the core product/service (technical dimension), the quality of the interpersonal relationships (social dimension) and the financial costs and benefits attached to the relationship (economic dimension).

More recently, Roberts (1998) and Roberts et al. (2000) review the dimensions on relationship quality that have been proposed in the literature and find that most of the 
studies have not examined the measure of relationship quality systematically and that different authors have proposed different dimensions. They themselves employ Bagozzi's (1984) framework in order to define relationship quality: attributional definition, structural definition and dispositional definition. The structural definition tells how relationship quality is linked to other related concepts, such as service quality (Crosby et al. 1990) and perceived service quality (Parasuraman et al., 1988). The dispositional definition describes the action tendencies or consequences of relationship quality, such as enhanced co-operation, on- going communication, decreased price sensitivity and increased word-of-mouth (McKenna 1995; Morgan et al. 1994; Reichheld 1996). The attributional definition is the most interesting one for the purposes of this article. Roberts et al. include six dimensions of relationship quality: trust in credibility, trust in benevolence, commitment, conflict, satisfaction and social bonding. Drawing upon the existing literature (such as in marketing and psychology), they proceed to define each of the dimensions (see table 1) sometimes using existing definitions (Roberts 1998; Roberts et al. 2000).

\section{Table 1. Dimensions of relationship quality - and their background and definition.}

\section{Dimension}

Trust in credibility

Trust in benevolence

Commitment

Conflict

Satisfaction

Social bonding
Background and definition

It has been argued that trust is a multi-dimensional construct and that two key dimensions are trust in credibility and trust in benevolence (Anderson et al., 1990; Ganesan, 1994; Kumar et al., 1995). Roberts $(1998$, p. 44) defines trust in credibility as follows. "Trust in a firm's credibility is based on the extent to which the customer believes that the firm's word can be relied upon, that they are sincere, and that they will perform their role effectively and reliably."

Trust in benevolence is, according to Roberts (1998, p. 44), as follows. "Trust in a firm's benevolence is the customer's perception of the extent to which the firm is concerned for the welfare of the customer. This includes having intentions and motives beneficial to the customer when new conditions arise for which a commitment was not made, and avoiding acting in a way that will result in negative outcomes for the customer."

It has been said that commitment is an important indicator of relationship quality (Moorman et al. 1992; Morgan et al. 1994). In the organisational literature, commitment may be affective commitment, continuance commitment or normative commitment (Meyer et al. 1993). Roberts et al. (2000, p. 9) argue that affective commitment is the important part of commitment when it comes to business relationships. "[Commitment] may be either affective commitment (attachment to firm), continuance commitment (perceived cost of leaving an organization), or normative commitment (perceived obligation to stay with an organization).... [Only] affective commitment influences the degree to which the consumer wants to maintain a relationship with the firm."

It has been contended that conflict is a negative indicator of relationship quality with greater negative affect leading to greater perceived risk and lower levels of relationship quality (Chaudhuri, 1998; Raven et al., 1970). Roberts $(1998$, p. 51) found that conflict is made up of affective conflict and manifest conflict. "Conflict is the tension between two or more social entities that arises from the incompatibility of actual and desired responses. Affective conflict is defined as hostility, frustration and anger towards a partner. This can develop into manifest conflict, which involves behavioural responses, such as open expression of disagreement or overt attempts to block the other's goal attainment."

It has been noted that satisfaction provides an evaluation of the quality of all past interactions with the service provider, and shapes expectations about the quality of future interactions (Crosby et al. 1990; Storbacka et al. 1994). Based upon that, Roberts et al. (2000) find that Storbacka et al. (1994, p. 25) offer the best definition. "Customer satisfaction is the customers' cognitive and affective evaluation based on their personal experience across all service episodes within the relationship."

It has been stated that social bonding is an important indicator of relationship quality (Barnes, 1997; Berry, 1995; Czepiel, 1990; Parasuraman et al., 1991; Wilson, 1995). Roberts (1998, p. 56) defines social bonding as follows. "Social bonds are present to the degree that the consumer is recognised by and enjoys interacting with their service provider. Higher levels of social bonding will resemble friendship."

Source: The table draws upon Roberts (1998) and Roberts et al. (2000) and Storbacka et al. (1994). 
But does it really make sense to employ relationship quality as a concept in relationship marketing and management? Are the six dimensions, presented by Roberts (1998) and Roberts et al. (2000) as indicators of relationship quality, really appropriate indicators?

As mentioned earlier, there have been very few empirical studies on what constitutes relationship quality - with Holmlund (1996, 1997) and Roberts (1998) and Roberts et al. (2000) as notable exceptions - and the literature review which was carried out did not identify any such studies within the agribusiness and the food industry context. There is, therefore, an evident need to develop more knowledge on both relationship quality and the relationship between relationship quality, customer retention and shareholder value. This first part of a larger research was undertaken in order to gain a better understanding of what constitutes relationship quality.

\section{Research methodology}

\section{Case study method}

The research falls naturally into two parts: an exploratory, qualitative first part and a confirmative, quantitative second part. Only the first part is reported on here. Deductive theory building was difficult because there is no consensus as to what constitutes relationship quality, which is both a contemporary and pre-paradigmatic phenomenon. As a result, it should be investigated within its real-life context. The case study method, which takes a holistic perspective on real-life phenomena with all of their potentially rich and meaningful characteristics intact, facilitates the exploration of complex concepts. Uniquely, the method avoids the need to pre-select the context type variables to be included in the investigation; instead, important contextual variables impinging on the behaviour of interest is observed over time (Creswell 1994; Eisenhardt 1989; Yin 1994). This means that the case study method offered the researcher the opportunity to investigate whether the six dimensions suggested by Roberts (1998) and Roberts et al. (2000) are an appropriate framework for describing relationship quality, or whether other dimensions should be included as indicators.

\section{Contextual setting}

The British food and beverage market was believed to be an interesting context. Britain imports food and beverage products from sectors where it does not have an inherent competitive disadvantage. The reason has been said to be more associated with strong relationships between the foreign exporter and the British importer than with efficiency of production (Shaw, 1994; Wilson et al., 1997; Woolven, 1996). Denmark and New Zealand have traditionally been among the major producers and exporters of products for the British consumer (Shaw, 1994; Tansey et al., 1995; Woolven, 1996). The Danish-British dairy sector, the DanishBritish bacon sector and the New Zealand-British wine sector were chosen specifically as appropriate contexts.

Which cases should then be included? It is important to appreciate that the case study method does not depend on numbers for epistemological justification. Cases should instead be added until theoretical saturation is reached (Eisenhardt 1989). In meetings with trade organisations (i.e., The Danish Bacon and Meat Council; The Danish Dairy Board; The Danish Institute of Agricultural and Fisheries Economics; The Wine Institute of New Zealand), the sample of cases was determined (see table 2).

Most studies on buyer-seller relationships have collected data from a single party in the dyad but such data is often misleading as only one side of the story is examined (Anderson, 1994; Iaccobucci et al., 1996). This is why this research focused on the exporter-importer dyad in order to correlate perceptions from both the exporter and the importer and to investigate the convergence of the two parties' views (see Table 2). At times, a dyadic approach was not possible, however. For example, confidentiality combined with a fragile business relationship between the two entities - was a problem in the case of Corbans Wine. In other cases, the British importer did not wish to participate in the research because of time pressure. Geographical proximity (Gummesson 1991) was yet another problem. The research consists of 24 cases in all, i.e. it is a multiple case study.

\section{Theory development from case study data}

To induct theory from the case studies, the eight-step procedure proposed by Eisenhardt (1989) was followed. The most important steps are explained below. The overall research problems were first identified to avoid loss of focus:

Does it make sense to employ relationship quality as a concept in relationship marketing and management?

If so, are the six dimensions proposed by Roberts (1998) and Roberts et al. (2000) appropriate indicators of relationship quality?

With potentially important indicators of relationship quality specified and with the cases selected, an interview protocol was crafted. Although the case study orientation is generally toward multiple sources of evidence (Yin 1994) in order to refine otherwise fallible observations (Creswell, 1994; 
Table 2. Sampling of cases and dyads for the Danish-British dairy sector, the Danish-British bacon sector and the New Zealand-British wine sector.

\section{Sector}

The Danish-British

The Danish-British bacon sector

The New ZealandBritish wine sector

$$
\text { Case }(s)^{\mathrm{a}}
$$

$$
\operatorname{Dyad}(s)^{b}
$$

The research included MD Foods. More than 90 per cent of all Danish milk is processed at MD Foods that is the only Danish dairy company with a significant export to Britain. After merging with Arla to form Arla Foods, MD Foods is now the largest dairy company in all Europe.

The research also included the Danish Dairy Board as a 'background case study'.

The research included two of the four meat-processing plants in Denmark: Danish Crown and Vestjyske Slagterier. (Of the remaining plants, Steff-Houlberg is oriented strongly toward the Danish market and TiCan has only recently installed its own marketing and distribution activities). The research also included Tulip International (that distributes all bacon products from Danish Crown) and ESS-Food (that distributes some 20 per cent of all Danish pork and pig meat products).

The research also included the Danish Bacon and Meat Council and the Danish Institute of Agricultural and Fisheries Economics as 'background case studies'.

The criteria for the vineyards to be included in the research were as follows. They should be of different sizes; it should not be too difficult to get to a particular vineyard; and the vineyards should export to Britain. Five small-sized vineyards (Goldwater Estate, Kumeu River Wines, Te Mata Estate Winery, Trinity Hill and Waiheke Vineyards), two medium-sized vineyards (Babich Wines, Hunter's Wines) and two large-sized vineyards (Corbans Wines and Villa Maria Estate) were included in the research.

The research also included the Wine Institute of New Zealand as a 'background case study'.

\author{
Vestjyske Slagterier - Roach \\ Foods \\ Tulip International - Tesco \\ ESS-Food - Bearfields
}

\author{
Kumeu River Wines - Boxford \\ Wine \\ Trinity Hill - Laurent-Perrier \\ Babich Wines - Percy Fox
} aThe 18 cases (on the exporter side), which form part of the research, are italic; bThe six cases (on the importer side), which
form part of the research, are underlined. There are thus 24 cases in all.

Erlandson et al., 1993; Lincoln et al., 1985), the in-depth interview has widely been regarded as the single most important source of evidence when the aim is to understand complex phenomena and processes (Creswell 1994; Easton 1995; Glaser et al. 1967; Lincoln et al. 1985; Miles et al. 1994; Patton 1990). But the research also involved the collection and analysis of existing market intelligence; the analysis of archival data, such as annual company reports, business documents and customer records; and site observations. All of these multiple sources of evidence allowed for triangulation of the case study data, which Yin has likened to "the development of converging lines of inquiry" (Yin 1994: 92). In other words, the findings of a case study are likely to be more accurate if they are based upon many sources of information. Findings were evaluated through the common measures of validity and reliability issues (see table 3).

The analysis of interview data was carried out in two stages: within-case analysis involving write-ups for each case and cross-case analysis involving searches for cross-case patterns. With regard to within-case analysis, each individual case was analysed in a four-stage interactive process that was developed by Miles and Huberman (1994). At the stage of data reduction, the volume of data was condensed. This 
Table 3. Design tests and case study tactics that were employed in the research.

\begin{tabular}{|c|c|c|}
\hline Design test & Theoretical explanation of the construct & Case study tactics \\
\hline Construct validity & $\begin{array}{l}\text { Construct validity is to ensure that correct operational } \\
\text { measures have been established for the concepts that } \\
\text { are being studied. }\end{array}$ & $\begin{array}{l}\text { Multiple sources of evidence } \\
\text { Chain of evidence } \\
\text { Interview respondents reviewing } \\
\text { draft of case study report }\end{array}$ \\
\hline Internal validity & $\begin{array}{l}\text { Internal validity is to make sure that a causal } \\
\text { relationship - i.e., certain conditions lead to other } \\
\text { conditions - has been established. Internal validity is a } \\
\text { concern for explanatory or causal case studies but not } \\
\text { for exploratory or descriptive case studies, which do not } \\
\text { attempt to make causal statements. }\end{array}$ & $\begin{array}{l}\text { Pattern matching } \\
\text { Rival explanation as patterns } \\
\text { Explanation building } \\
\text { Time series analysis }\end{array}$ \\
\hline External validity & $\begin{array}{l}\text { External validity is to prove that the domain to which a } \\
\text { case study's findings belong can be generalised. }\end{array}$ & $\begin{array}{l}\text { Specification of the population of interest } \\
\text { Replication logic in multiple case studies }\end{array}$ \\
\hline Reliability & $\begin{array}{l}\text { Reliability involves demonstrating that the findings } \\
\text { from a case study can be repeated if the case study } \\
\text { procedures are followed. }\end{array}$ & $\begin{array}{l}\text { Interview protocol } \\
\text { Clearly conceptualised constructs } \\
\text { Multiple indicators } \\
\text { Execution of pilot tests } \\
\text { Case study data base }\end{array}$ \\
\hline
\end{tabular}

Source: The table draws upon Yin (1994) with regards to the theoretical explanation of the constructs. All of the tactics mentioned in the table were employed during the research in order to triangulate the case study data.

also happened in the middle stages of the research through coding and memoing (see below) as well as in the activities of finding themes, clusters and patterns. In the later stages of the research, data reduction occurred when ideas where conceptualised and explained. In order not to reduce data so much that significant information is lost, the research was not stripped from its context (Punch 1998), as evidenced by the many text units (see below). In terms of coding, the researcher put labels against pieces of the data (Glaser 1978; Miles et al. 1994; Punch 1998). That is, the coding consisted of summarising the data by pulling together themes and identifying patterns. The approach was to employ a prespecified coding scheme (Lindgreen 2001) that drew heavily on the six dimensions of relationship quality but also on other constructs that have been suggested as important in relationship marketing and management. In terms of memoing, the researcher sought new patterns and a higher level of pattern coding.

With regard to cross-case analysis, one method was to look for inter-group differences in the indicators of relationship quality. Another one was to list similarities and differences between sets of cases. Yet a third method was to divide the data by source and then to establish whether the sources resulted in the same pattern.

\section{Exploratory findings}

The quality of the relationship between the exporter and the importer was found to be key, as evidenced in the following text units:

"I would like to say that when we talk about relationships, the way that we work is very much about relationships." Marketing director, ESS-Food.

"You need a relationship with customers, suppliers, staff, management - it goes right through the whole business." Marketing director, Bearfields.

"I don't think that our marketing is particularly sophisticated or clever ... The key feature of ours is that we are in networks ... I would switch on the network [when trying to locate a new distributor]. We have found that we virtually don't have to move outside of the networks that we are in." General manager (Name of vineyard withheld for confidentiality reasons).

Overall, the research found strong empirical evidence that relationship quality is made up of the six constructs that Roberts (1998) and Roberts et al. (2000) propose. Although the case study may take a variety of forms (Yin 1994), the 

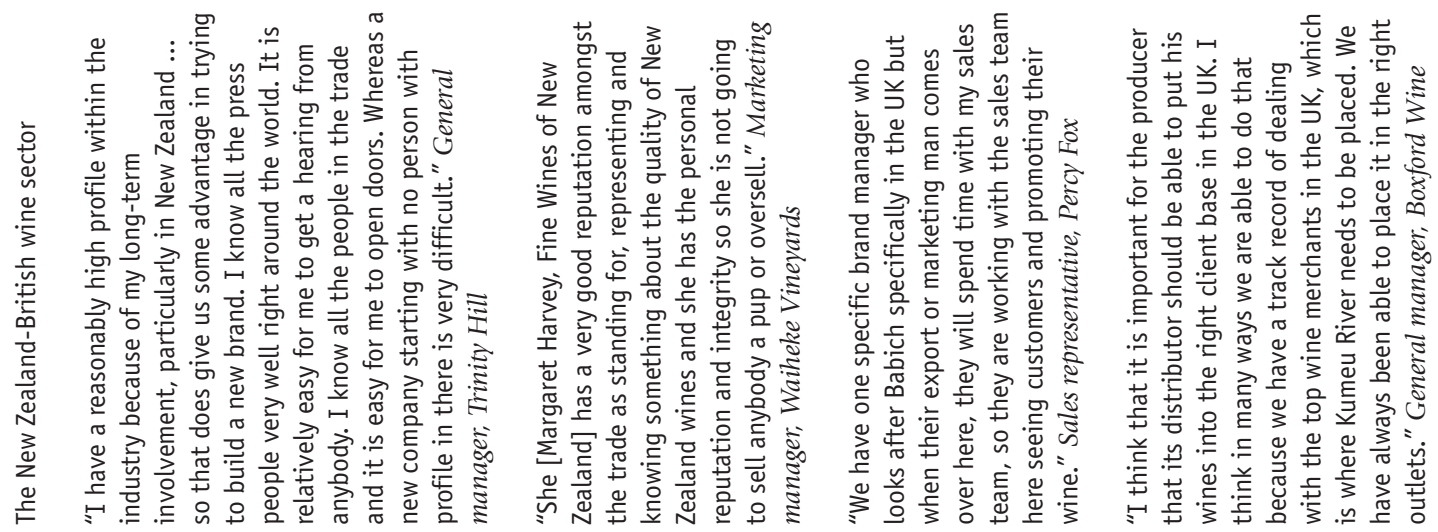

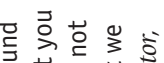

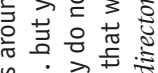

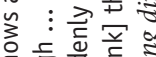

它总离产总

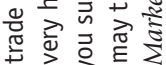

范. .

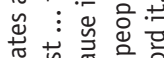

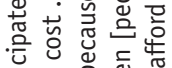

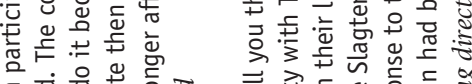

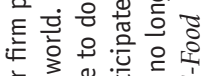

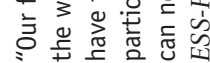

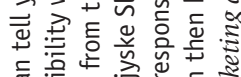

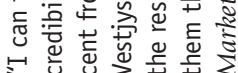

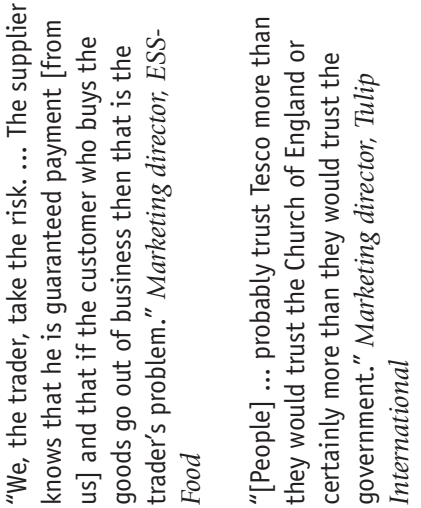

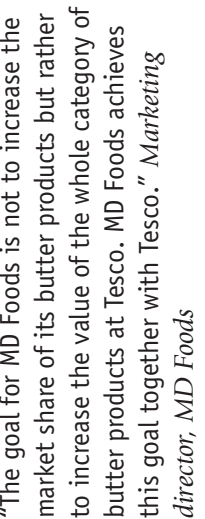




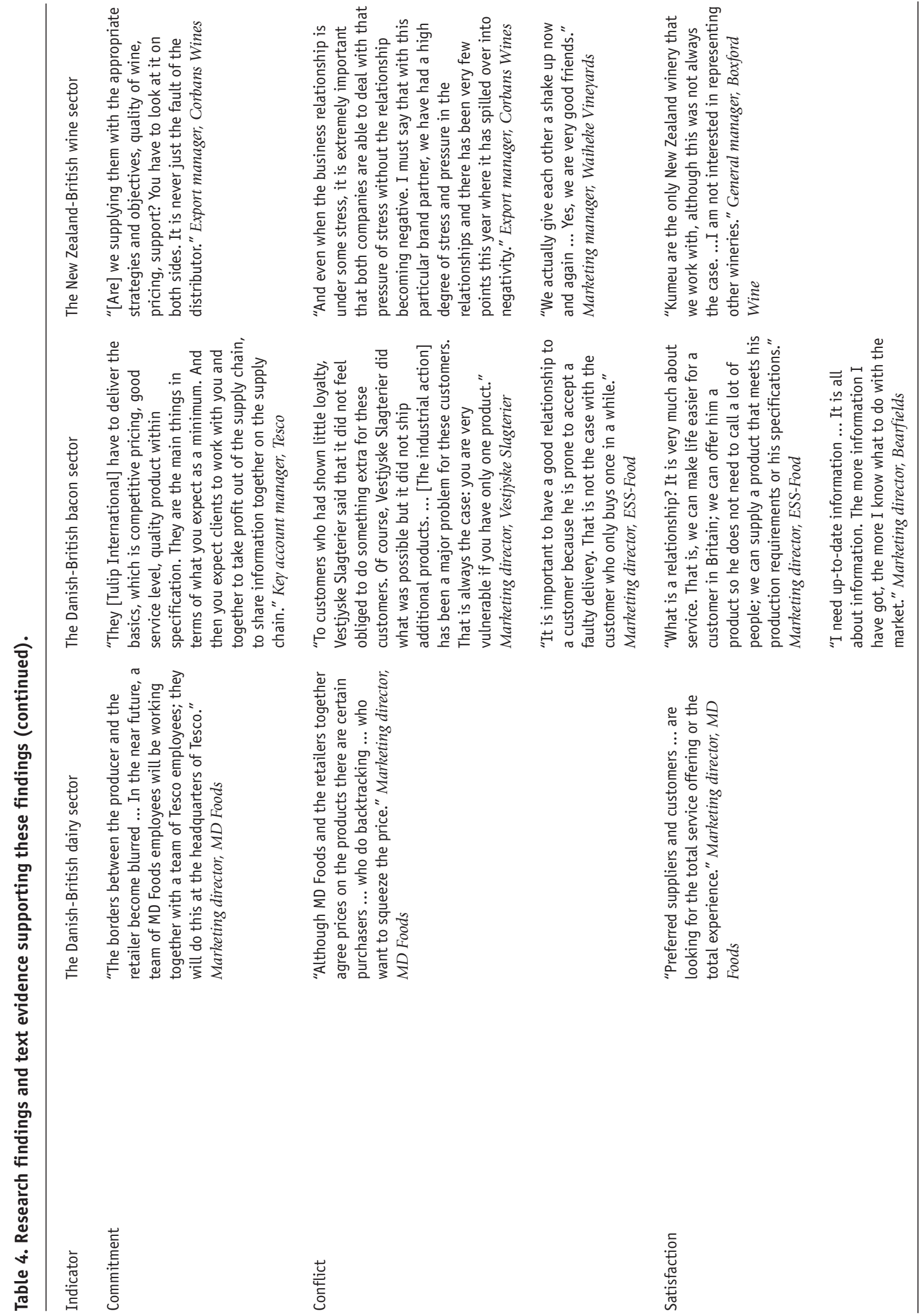




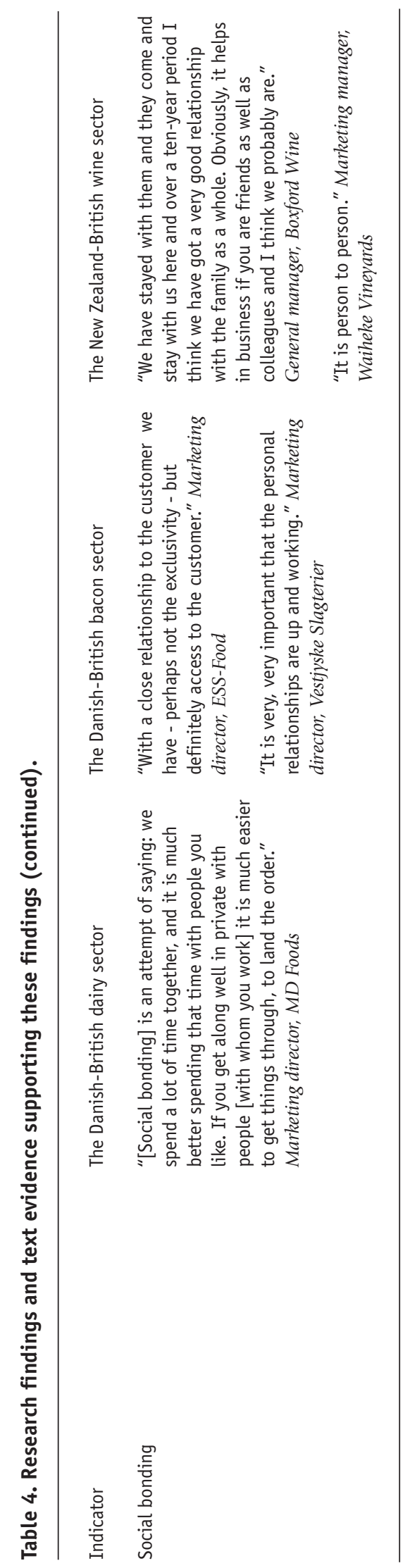


essential characteristic is that the report contains explicit presentations of the key evidence that were used to draw the conclusions. This, however, makes the case study reporting discursive and readers find the lengthy description of results exhausting. Therefore, a number of text units supporting the research findings have been collected in Table 4 so that in the following only a few examples are given to show the appropriateness of the six dimensions of relationship quality.

\section{Trust in credibility and trust in benevolence}

The two constructs of trust in credibility and trust in benevolence were found to be important in exporterimporter dyads. An importer thus places much trust in a vineyard's credibility if the vineyard produces wines of consistently high quality and/or if the people working with the vineyard have in-depth knowledge of the wine sector and a prominent position within the wine community:

"I think it [trust in credibility] depends on the quality of the wine, and in our case we are New Zealand's most highly awarded wine company and that has given us credibility amongst all of our distributors." Export manager, Villa Maria Estate.

"I think [that] anybody who has met the family [Brajkovich] understands the respect with which they are regarded within the New Zealand wine trade. It would be impossible not to trust them. Their late father was highly regarded and respected within the New Zealand wine trade ... and the rest of the family is held in similar regard." General manager, Boxford Wine.

An importer can improve his credibility by choosing to represent only the best wines and/or to go the extra mile for the exporter when identifying the best outlet for the wines:

"It is important that the product be distributed throughout the best wine merchants ... We could, if we wanted to, actually sell all the wine through just two outlets but I do not think that [this] is the long-term benefit of Kumeu River." General manager, Boxford Wine

Frequent and forthright communication between the parties was found to foster trust in benevolence, as echoed in the following text unit:

"I think that a customer appreciates a flow of information. You must be able to supply information about what is happening in the market ... If you cannot do this the customer will be very unhappy and probably leave you." Marketing director, ESS-Food

\section{Social bonding}

The social bonding that was mentioned is a key element. For example, the general manager of a New Zealand vineyard argued that his network has been the single most important factor in the success of the vineyard, as evidenced in the last of the above three statements. The general manager first served his apprenticeship with Firm A before buying Firm $\mathrm{B}$, a chain of specialist wine shops in London. At the same time, because he attended night school, he became part of a network consisting of similar young people who later went on to senior positions in the wine trade. The value of the network has been evident:

"Because I knew everybody in the English wine trade, it was not a matter of me finding someone to sell it. I was just dealing with friends. When I walked in they did not just say: 'oh, New Zealand wine, forget it."' General manager (Name of vineyard withheld for confidentiality reasons).

The manager of the vineyard does not move outside the network so when the vineyard wants to develop a new wine market (in a new country) it will ask its current importers to signal to their colleagues in the new wine market that the vineyard is available for distribution. A formal interview and evaluation process will then take place during which the vineyard will confer with the existing importers:

"We have found that we virtually do not have to move outside of the networks that we are in. That is fine because you know where all your money is going and whether you are going to get paid or not and how your goods are going to be sold and presented and all the things that are important. It is the easiest way to do it when you are a small player based in New Zealand." General manager (Name of vineyard withheld for confidentiality reasons).

With regard to the British wine market, the vineyard decided to let Firm C distribute its wines, partly because this firm is widely known within the British wine trade. But the single most important reason the vineyard chose this particular importer was that the general manager had worked in the company back in the 1960s and he has been close friends with the importer ever since, as evidenced in the following text unit:

"I worked for the [Firm C] in [the 1960s] and we are close friends ... We are all in bed together, and we are throughout 
the world." General manager (Name of vineyard withheld for confidentiality reasons).

\section{Commitment}

The research findings suggest that successful export-importer relationships were characterised by a high degree of commitment from both parties. MD Foods - the Danish dairy firm - and its business partners (i.e., suppliers and customers) is a case in point: MD Foods will assess potential business partners and only when a partner demonstrates enough good will, skill and importance is the firm ready to invest in a relationship:

"With regard to importance, if a customer has only little importance for MD Foods then it really does not matter whether this customer has the necessary will and skill ... It is important to realise that we commit substantive resources to a business partnership." Marketing director, MD Foods.

When a partner shows promise, MD Foods seeks to build and strengthen the relationship. For example, MD Foods' only remaining bottle supplier is now conveniently located next to the headquarters of MD Foods and that makes cooperation and co-ordination easier: business processes are thus fully integrated through the SAP R/3 systems. Another example is Tesco, which is one of MD Foods' most important customers: In this case, MD Foods had to demonstrate will, skill and importance before it was nominated as one of Tesco's preferred suppliers of butter. The commitment to the business relationship in both cases is strong, as evidenced in the following text units:

"In the near future, a team of MD Foods employees will be working together with a team of Tesco employees. They will do this at the headquarters of Tesco." Marketing director, MD Foods.

"MD Foods brings the chief executive ... to Denmark in a private jet ... It is not a question of money ... We get value for our money because it is possible for us to become a player." Marketing director, MD Foods.

In conclusion, the evidence suggests that (1) it does make sense to employ relationship quality as a concept in relationship marketing and management, and that (2) the six dimensions that Roberts (1998) and Roberts et al. (2000) argue are indicators of relationship quality really are appropriate indicators.

\section{Managerial Implications}

One of the most important managerial implications of the research findings is that companies should now consider not only the quality of their products and services but also the quality of their relationships with suppliers, customers and other important markets. A high-quality relationship translates into customer retention and, subsequently, shareholder value creation (see the Future Research section). It is possible to improve the quality of a relationship by investing in one (or more) of six different areas: trust in credibility, trust in benevolence, commitment, conflict, satisfaction and social bonding. For example, employees might be encouraged to form social bonds with their business partners ("Obviously, it helps in business if you are friends as well as colleagues", General manager, Boxford Wine), perhaps to such an extent that it becomes difficult to distinguish between a business relationship and a friendship ("We are very good friends", Marketing manager, Waiheke Vineyards). Another example is for partners to demonstrate that they are trustworthy ("A word is a word ... If we have agreed on a price then we do not change that price", Marketing director, ESS-Food).

Another equally important managerial implication is that companies must invest in their employees, since relationships are formed between employees from separate companies ("It is about multi-level contact in each area in the organisation, regular and structured communication", Export manager, Corbans Wines). This again means that managers should assess not only the relationships with their business partners but also with the employees within their company. A third managerial implication of the research findings is that managers should put less emphasis on developing close business relationships by using economic incentives or computer-based systems (as many customer relationship management systems appear to be doing), as these are easy to duplicate. Instead managers should cultivate their relationships, because it is difficult for competitors to offer similar ones, as it takes much effort and many years to build strong relationships ("It [the forming of close relationships] does not happen overnight. It can take quite a while", Export manager, Villa Maria Estate).

\section{Future research}

This article has focused on the indicators of relationship quality. However, the evidence from the research also suggests that relationship quality translates first into customer retention and then shareholder value creation (see figure 1): there is thus a positive relationship between all of the antecedents and relationship quality (except for conflict), and there is a positive relationship between 


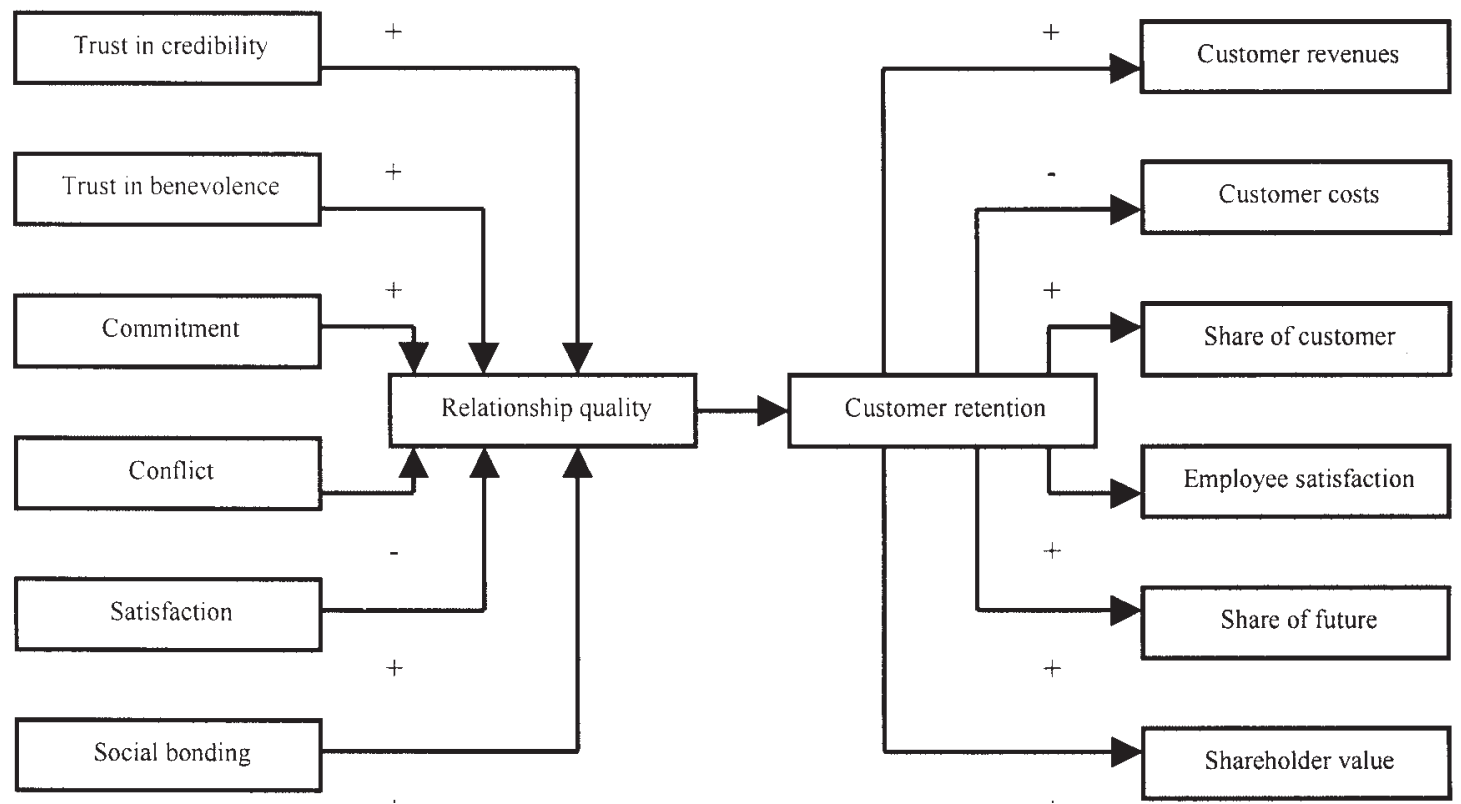

Figure 1. The relationship quality - customer retention theory of shareholder value creation.

customer retention and all of the consequences (except for customer costs).

The proposed relationship quality - customer retention theory of shareholder value creation is parsimonious, permitting no direct path from any of the antecedents of relationship quality to any of the consequences of customer satisfaction. The model implies a central nomological status for relationship quality - customer retention.

It is proposed to test the idea of Figure 1 in a confirmative, quantitative second part of the research. In structural equations modelling, however, rival models should be compared (Bollen et al., 1992; Morgan et al., 1994). A nonparsimonious rival model is one that positions only direct paths from each of the pre-cursors to the outcomes, thereby making relationship quality and customer retention nomologically similar to the antecedents of relationship quality and thus allowing no indirect effects (i.e., relationship quality and customer retention cannot mediate any of the relationships). There is a positive relationship between all of the pre-cursors (except for conflict) and the outcomes (except for customer costs).

The New Zealand-British wine sector is proposed as an appropriate research setting. There are many independent vineyards with only few elements of vertical integration. Because most of the vineyards carry only a small number of wine labels, their relationships with British importers are potentially important enough for the research issue to be meaningful. Restricting the sample to this homogeneous population, extraneous sources of variation are minimised. The relatively large number of vineyards (more than 300) and extreme competitive pressures from other producing countries, such as Australia, the US and Chile, increase the likelihood of there being large variance to be explained (please refer to Appendix A).

\section{References}

Anderson, J.C. and J.A. Narus, (1990), A model of distributor firm and manufacturing firm working partnership, Journal of Marketing, Vol. 54, No. 1, pp. 42-58.

Anderson, W.T. (1994), Deciphering dyads: concepts, methods, and controversies in relational research, Psychology \& Marketing, Vol. 11, No. 5, pp. 447-466.

Bagozzi, R.P. (1984), A prospectus for theory construction in marketing, Journal of Marketing, Vol. 48, Issue 1, pp. 11-29.

Barkema, A. (1992), Reaching consumers in the twenty-first century: the short way around the barn, American Journal of Agricultural Economics, Vol. 74, pp. 1126-1131.

Barnes, J.G. (1997), Closeness, strength, and satisfaction: examining the nature of relationships between providers of financial services and their retail customers, Psychology \& Marketing, Vol. 14, No. 8, pp. 765-790.

Barry, P.J., S. T Sonka and K. Lajili (1992), Vertical coordination, financial structure, and the changing theory of the firm, American Journal of Agricultural Economics, Vol. 74, pp. 1219-1225.

Behner, M. and V. Bitsch (1995), Abnehmer-LieferantenBeziehungen im Produktionsgartenbau. Eine transaktionskostentheoretische Analyse, Agrarwitschaft, Vol. 44, pp. 131-137. 
Berry, L.L. (1983), Relationship marketing, in Berry, L.L., Shostack, G.L. and Upah, G.D. (Eds.), Emerging Perspectives on Services Marketing, American Marketing Association, Chicago, USA, Illinois, pp. 25-28.

Berry, L.L. (1995), Relationship marketing of services - growing interest, emerging perspectives, Journal of Academy of Marketing Science, Vol. 23, No. 4, pp. 236-245.

Bollen, K. and J.S. Long (1992), Tests for structural equation models: introduction, Sociological Methods and Research, Vol. 21, November, pp. 123-131.

Bolton, W. and J.H. Drew (1991), A multistage model of customers' assessment of service quality and value, Journal of Consumer Research, Vol. 17, No. 4, pp. 375-384.

Brodie, R.J., N.E. Coviello, R.W Brookes and V. Little (1997), Towards a paradigm shift in marketing? An examination of current marketing practices, Journal of Marketing Management, Vol. 13, No. 5, pp. 383-406.

Buttle, F. (1996), Relationship marketing, in Buttle, F. (Ed.), Relationship Marketing: Theory and Practice, Paul Chapman Publishing, London, UK, pp. 1-16.

Buttle, F., P. Naudé, C.G. Myhal and P. Hopkinson, P. (2000), Exploring relationship quality, competitive paper for the Biennial International Conference of the American Marketing Association, 28 June - 1 July, Universidad Torcuato Di Tella, Buenos Aires, Argentina.

Carlell, C. and A. Mägi (1999), Relationship marketing from the consumer perspective: are customers interested in bonding with companies? in Hildebrandt, L., Annacker, D. and Klapper, D. (Eds.), Marketing and Competition in the Information Age: Proceedings of the 28th EMAC Conference, 11-14 May, Humboldt University Berlin, Berlin, Germany.

Chaudhuri, A. (1998), Product class effects on perceived risk: the role of emotion, International Journal of Research in Marketing, Vol. 15, Issue 2, pp. 157-168.

Christopher, M., A. Payne and D. Ballantyne (1991), Relationship Marketing: Bringing quality, customer service, and marketing together, Butterworth-Heinemann, Oxford, UK.

Collins, B.A. (1999), Pairing relationship value and marketing, Australasian Marketing Journal, Vol. 7, No. 1, pp. 63-71.

Cooper, M.C., J.T. Gardner and E.B. Pullins (1997), A benchmark bibliometric approach to identifying the state of theory development in relationship marketing, in Meenaghan, T. (Ed.) (1997), Proceedings of the AMA Relationship Marketing Conference, June, University College Dublin and American Marketing Association, Dublin, Ireland, pp. 187-203.

Creswell, J.W. (1994), Research Design: Qualitative and Quantitative Approaches, Sage Publications, Thousand Oaks, California, USA.

Crosby, L.A., K.R. Evans and Cowles, D. (1990), Relationship quality in services selling: an interpersonal influence perspective, Journal of Marketing, Vol. 54, pp. 68-81.
Czepiel, J.A. (1990), Service encounters and service relationships: implications for research, Journal of Business Research, Vol. 20, pp. 13-21.

Davies, G. (1996), Supply-chain relationships, in Buttle, F. (Ed.), Relationship Marketing: Theory and Practice, Paul Chapman Publishing, London, UK, pp. 17-28.

Easton, G. (1995), Methodology and industrial networks, in Möller, K. and Wilson, D. (Eds.), Business Marketing: An Interaction and Network Perspective, Kluwer Academic Publishers, Boston, Massachusetts, USA, pp. 411-492.

Eiriz, V. and D. Wilson (1999), Theoretical foundations and research priorities in relationship marketing, in Hildebrandt, L., Annacker, D. and Klapper, D. (Eds.), Marketing and Competition in the Information Age: Proceedings of the 28th EMAC Conference, 11-14 May, Humboldt University Berlin, Berlin, Germany.

Eisenhardt, K.M. (1989), Building theories from case study research Academy of Management Review, Vol. 14, No. 4, pp. 532-550.

Eriksson, K. and A.L. Vaghult (1999), Customer retention, purchasing behaviour and relationship substance in professional services, in McLoughlin, D. and Horan, C. (Eds.), Proceedings of the 15th Annual IMP Conference, 2-4 September, University College Dublin, Dublin, Ireland.

Erlandson, D.A., E. L. Harris, B.L. Skipper and S. D. Allen (1993), Doing Naturalistic Inquiry: A Guide to Methods, Sage, Newbury Park, California, USA.

Fontenot, R.J. and E. J. Wilson (1997), Relational exchange: a review of selected models for a prediction matrix of relationship activities, Journal of Business Research, Vol. 39, No. 1, pp. 5-12.

Fornell, C. (1992), A national satisfaction barometer: the Swedish experience, Journal of Marketing, Vol. 56, No. 1, pp. 1-21.

Frisou, J. (1995), Alternatives de choix et fidélité a l'opérateur sur le marché residential des services de telecommunications: une approche marketing, Recherche et Applications en Marketing, Vol. 10, No. 3, pp. 17-32.

Ganesan, S. (1994), Determinants of long-term orientation in buyer-seller relationships, Journal of Marketing, Vol. 58, No. 4, pp. 1-19.

Glaser, B. (1978), Theoretical Sensitivity, Sociology Press, Mill Valley, California, USA.

Glaser, B. and A. Strauss (1967), The Discovery of Grounded Theory: Strategies for Qualitative Research, Aldine, New York, USA.

Goderis, J.-P. (1998), Barrier marketing: from customer satisfaction to customer loyalty, CEMS Business Review, Vol. 2, No. 4, pp. 285-294.

Grönroos, C. (2000), Service Management and Marketing: A Customer Relationship Management Approach, 2nd ed., Wiley, Chichester, UK.

Gummesson, E. (1991), Qualitative Methods in Management Research, Sage Publications, Newbury Park, California, USA. 
Gummesson, E. (1997), Emerging approaches to return on relationships, in Christopher, M. and Payne, A. (Eds.), Proceedings of the 5th International Colloquium in Relationship Marketing, Cranfield School of Management, Cranfield, UK, pp. 9-23.

Gummesson, E. (1998), Total relationship marketing: experimenting with a synthesis of research frontiers, competitive paper for 6 th International Colloquium in Relationship Marketing, 7-8 December, University of Auckland, Auckland, New Zealand.

Gummesson, E. (1999), Total Relationship Marketing: From the 4Ps - product, price, promotion, place - of traditional marketing management to the 30Rs - the thirty relationships - of the new marketing paradigm, Butterworth-Heinemann, Oxford, UK

Harker, M.J. (1999), Relationship marketing defined? An examination of current relationship marketing definitions, Marketing Intelligence \& Planning, Vol. 17, No. 1, pp. 13-20.

Holmlund, M. (1996), A Theoretical Framework of Perceived Quality in Business Relationships, Ekonomi och Samhälle No. 36, Swedish School of Economics and Business Administration, Helsingfors, Finland.

Holmlund, M. (1997), Perceived Quality in Business Relationships, Ekonomi och Samhälle No. 66, Swedish School of Economics and Business Administration, Helsingfors, Finland.

Hopkinson, P. (2000), Relationship quality: literature review, unpublished report, Gloucestershire Business School, UK.

Hughes, D. (1994), Breaking With Tradition: Building Partnerships \& Alliances in the European Food Industry, Wye College Press, Wye, UK.

Iaccobucci, D. and P.C. Zerillo (1996), Multiple levels of relational marketing phenomenon, in Iaccobucci, D. (Ed.), Networks in Marketing, Sage Publications, Thousand Oaks, California, USA, pp. 387-409.

Kalfass, H.H. (1993), Kostenvorteile durch vertikale Integration im Agrarsektor? Agrarwirtschaft, Vol. 42, pp. 228-237.

Kumar, N., L.K. Scheer and J.E.M. Steenkamp (1995), The effects of supplier fairness on vulnerable resellers, Journal of Marketing Research, Vol. 32, pp. 54-65.

Lehmann, A. (1997), Supply chain management - eller bare sund fornuft? Berlingske Tidende, 28 January, p. 12.

Lewin, J.E. and W.J. Johnston,(1997), Relationship marketing theory in practice: a case study, Journal of Business Research, Vol. 39, No. 1, pp. 23-31.

Lincoln, Y.S. and E.G. Guba (1985), Naturalistic Inquiry, Sage, Beverly Hills, California, USA.

Lindgreen, A. (2001), A framework for studying relationship marketing dyads, Qualitative Market Research - An International Journal, No. 3 or No. 4, forthcoming.

Lindgreen, A. and I. Crawford (1999), Implementing, monitoring and measuring a programme of relationship marketing, Marketing Intelligence \& Planning, Vol. 17, No. 5, pp. 231-239. McKenna, R. (1995), Real-time marketing, Harvard Business Review, July-August, pp. 87-95.
Meyer, J.P., N.J. Allen and C.A. Smith (1993), Commitment to organizations and occupations: extension and test of a threecomponent conceptualization, Journal of Applied Psychology, Vol. 78, No. 4, pp. 538-551.

Miles, B. and A.M. Huberman, (1994), Qualitative Data Analysis: An Expanded Sourcebook, 2nd edition, Sage Publications, Thousand Oaks, California, USA.

Mohr, J. and R. Spekman (1994), Characteristics of partnership success: partnership attributes, communication behavior, and conflict resolution techniques, Strategic Management Journal, Vol. 15, No. 2, pp. 135-152.

Moorman, C.R., G. Zaltman and R. Deshpande (1992), Relationships between providers and users of market research: the dynamics of trust within and between organizations, Journal of Marketing Research, Vol. 26, pp. 314-329.

Morgan, R.M. and S.D. Hunt (1994), The commitment-trust theory of relationship marketing, Journal of Marketing, Vol. 58, No. 3, pp. 20-38.

O'Neal, C. (1989), JIT procurement and relationship marketing, Industrial Marketing Management, Vol. 18, No. 1, pp. 55-63.

Page, N. and B. Sharp (1998), The defining elements of relationship quality: the story so far, in Andersson, P. (Ed.), Proceedings of the 27th Annual Conference of the European Marketing Academy, Elanders Gotab, Stockholm, Sweden, Vol. 1, pp. 331-344.

Parasuraman, A., L.L. Berry and V.A. Zeithaml (1991), Understanding customer expectations of service, Sloan Management Review, pp. 39-47.

Parasuraman, A., V.A. Zeithaml and L.L Berry (1988), SERVQUAL: a multiple-item scale for measuring consumer perceptions of service quality, Journal of Retailing, Vol. 64, No. 1, pp. 12-40.

Patton, M.Q. (1990), Qualitative Evaluation and Research Methods, Sage Publications, Newbury Park, California, USA.

Punch, K.F. (1998), Introduction to Social Research: Quantitative and Qualitative Approaches, Sage Publications, Thousand Oaks, California, USA.

Raven, B. and A. Kruglanski (1970), Conflict and power, in Steiner, I. and Fishbein, M. (Eds.), Current Studies in Social Psychology, Holt, Rinehart, and Winston, New York, USA, pp. 371-382.

Reichheld, F.F. (1996), The Loyalty Effect: The Hidden Force Behind Growth, Profits, and Lasting Value, Harvard Business School Press, Boston, Massachusetts, USA.

Roberts, K.T. (1998), Assessing the Value of Relationship Quality in Comparison with SERVQUAL: A Scale Development and Evaluation, unpublished MA thesis, University of Auckland, Auckland, New Zealand.

Roberts, K., S. Varki and R. Brodie (2000), Measuring the quality of relationships in services: an empirical study, School of Business and Economics Working Papers Series, University of Auckland, Auckland, New Zealand.

Rosenbloom, B. (1991), Marketing Channels: A Management View, Dryden, Hinsdale, Illinois, USA. 
Scheuing, E.E. (1995), Creating Customers for Life, Productivity Press, Portland, Oregon, USA.

Shaw, S.A. (1994), Competitiveness, relationships and the Strathclyde University Food Project, Journal of Marketing Management, Vol. 10, No. 5, pp. 391-407.

Snehota, I. and M. Söderlund (1998), Relationship marketing what does it promise and what does it deliver? An empirical examination of repeat purchase customers, in Andersson, P. (Ed.), Proceedings of the 27th Annual Conference of the European Marketing Academy, Elanders Gotab, Stockholm, Sweden, Vol. 1, pp. 311-330.

Sporleder, T.L. (1992), Managerial economics of vertically coordinated agricultural firms, American Journal of Agricultural Economics, Vol. 74, pp. 1226-1231.

Srivastava, R., G.-W. Ziggers and L. Schrader (1998), Vertical coordination in the swine industry: a multi-country study, in Ziggers, G.W., Trienekens, J.H. and Zuurbier, P.J.P. (Eds.), Proceedings of the 3rd International Conference on Chain Management in Agribusiness and the Food Industry, Wageningen Agricultural University, Wageningen, the Netherlands, pp. 269280.

Stern, L.W. and A. El-Ansary (1992), Marketing Channels, 4th ed., Prentice-Hall, Englewood Cliffs, New Jersey, USA.

Storbacka, K., T. Strandvik and C. Grönroos (1994), Managing customer relationships for profit: the dynamics of relationship quality, International Journal of Service Industry Management, Vol. 5, No. 5, pp. 21-38.

Tansey, G. and T. Worsley (1995), The Food System: A guide, Earthscan Publications, London, UK.

Wilson, D.T. (1995), An integrated model of buyer-seller relationships, Journal of the Academy of Marketing Science, Vol. 23, No. 4, pp. 335-345.

Wilson, H. and M. Benson-Rea (1997), Coopers Creek and the New Zealand wine industry, in Johnson, G. and Scholes, K. (Eds.), Exploring Corporate Strategy: Text and Cases, 4th ed., Prentice Hall Europe, London, UK, pp. 691-702.

Woolven, J. (1996), Food Industry Forces of Change, IGD Business Publications, Watford. UK.

Yin, R.K. (1994), Case Study Research: Design and Methods, 2nd edition, Sage Publications, Thousand Oaks, California, USA.

Young, L.C. and I.F. Wilkinson (1989), The role of trust and cooperation in marketing channels: a preliminary study, European Journal of Marketing, Vol. 23, No. 2, pp. 109-122.

Zeithaml, V.A., L.L. Berry and A. Parasuraman (1996), The behavioral consequences of service quality, Journal of Marketing, Vol. 60, pp. 31-46. 